\title{
Maturity Level Knowledge Management System at Travelodge Batam Hotel using the Cobit 5 Framework
}

\author{
Sfenrianto, Muhamad Dody Firmansyah
}

\begin{abstract}
Advances in technology and science are increasing as a new challenge for companies that must manage knowledge assets for encourage the creation of knowledge management. Knowledge Management System (KMS) that already exists at a company like Travelodge Hotel Batam can run effectively, it is necessary to conduct an evaluation activity by examining how the process of managing knowledge possessed by each individual can be transferred to other individuals through the process of knowledge sharing. The study aim analyzes to find out the extent of the processes of knowledge level management found in Traveldoge Hotel Batam at the maturity level of the KMS. The Cobit 5 Framework Model used to evaluation the KMS in this company. The results of the analysis are maturity analysis ((AP07, BAI4, DSS3, DSS6, and MA01) and recommendation than expected to be an evaluation material that will have an impact on the KMS of company later.
\end{abstract}

Keywords: Knowledge, Knowledge Management, Knowledge Sharing, KMS, Cobit 5.

\section{INTRODUCTION}

Technological and knowledge advancements are increasing in line with new challenges for companies that have to manage knowledge assets that are integrated with collaboration, sharing, innovation, etc. To drive knowledge management should be Knowledge Management System (KMS) becomes the main tool. The KMS implementation, it is necessary to do an evaluation of maturity level.

Travelodge Batam Hotel is a four-star hotel in Batam City, Riau Islands province with 254 rooms and includes one Cendana Meeting Point Ballroom. The hotel has five departments, namely: Front Office, Housekeeping, Engineering, Accounting Finance, and Department of Human Resources (HRD). This company, also there are many diverse human resources, therefore the company has a lot of knowledge that must be managed well.

The process of sharing existing knowledge using KMS at the Travelodge Batam Hotel should be run effectively. It is

Revised Manuscript Received on April 25, 2020.

* Correspondence Author

Sfenrianto*, Information Systems Management Department, BINUS Graduate Program - Master of Information Systems Management, Bina Nusantara University, Jakarta 11480. Email: sfenrianto@binus.edu.

Muhamad Dody Firmansyah, Information Systems Management Department, BINUS Graduate Program - Master of Information Systems Management, Bina Nusantara University, Jakarta 11480. Email: dodyfirmansyah.dodi@gmail.com.

(C) The Authors. Published by Blue Eyes Intelligence Engineering and Sciences Publication (BEIESP). This is an open access article under the CC BY-NC-ND license (http://creativecommons.org/licenses/by-nc-nd/4.0/)

necessary to conduct an evaluation activity by requesting the process of knowledge needed by everyone to be transferred to other individuals through the process of sharing knowledge and knowledge presentation management. Thus, necessary to do an analysis to find out which processes require management knowledge levels needed at the maturity level of KMS. The results of the analysis can be expected to be an evaluation material that will have an impact on the company.

The COBIT 5 can be use evaluated problem of knowledge management with human resources in accordance with the level of maturity (level of maturity) on KMS. Through the Cobit 5 framework, the problem entered the APO7 domain (human resource domain) and EDM4 domain (ensuring human resource optimizer). Based on these problems, it is necessary to manage the KMS governance at Travelodge Hotel Batam. Evaluation of governance has the aim to determine the value of maturity (level of maturity) of corporate governance and give approval. Researchers use the COBIT 5 framework for governance arrangements in the company with several domains in accordance with what is happening

This is what chooses how to be seen until the maturity of the KMS Knowledge Management System model) at Travelodge Hotel Batam and contributes the results to collect to the same level as knowledge management...

\section{BASIC THEORY}

The process is a series of activities aimed at achieving several results. The process is a way how a job produces value for customers. Usually we talk about processes in the context of production: a set of activities and operations involved in changing inputs (physical, material, capital, equipment, and human facilities) to output (products and services) [1].

The model is describing the development of entities from time to time, with any entity that is interesting. Each entity develops through levels over time until it reaches the highest, optimized, level. Maturity models have the following properties according to Shekar Sivasubramanian in [2].

Knowledge Management system (KMS) is needed for developing employee knowledge in a company. The KMS is a process framework consisting of a place for storing knowledge, relationships, IT, communication infrastructure, functional expertise, environment, organizational intelligence and external resources [3].

Published By:

Blue Eyes Intelligence Engineering \& Sciences Publication

(C) Copyright: All rights reserved.

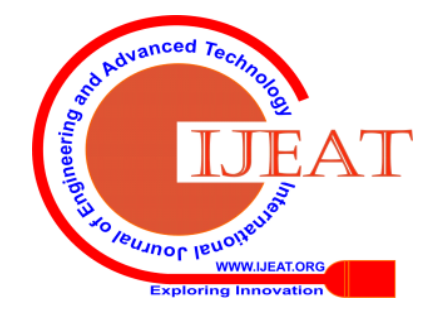


According to ISACA, COBIT 5 is the latest generation of ISACA guidelines that discuss IT governance and management [4]. There are COBIT 5 process such as: are Managing Human Relations (AP07), managing availability and capacity of resources (BAI4), managing problems (DSS3), managing and controlling (DSS6), and monitoring, evaluating, and evaluating performance and compliance (MEA1).

Measurement of the maturity level of a KMS is needed to determine the current maturity and expected maturity [5] [6]. A KMS maturity is the current position of knowledge management (current maturity) [7]. Furthermore, it is needed to determine the target maturity for each future knowledge process (expected maturity) [8]. Gap analysis on Cobit 5 is obtained from the difference by comparing the level between the current level of maturity and the expected level of maturity [9]] [10].

\section{RSEARCH METODE}

The research design contains the steps used in this study to be well structured. With this systematics the research process can be understood and followed. Research conducted to design a system is obtained from observing existing data. Gambar 1 shown, the steps taken to achieve the objectives of this research.

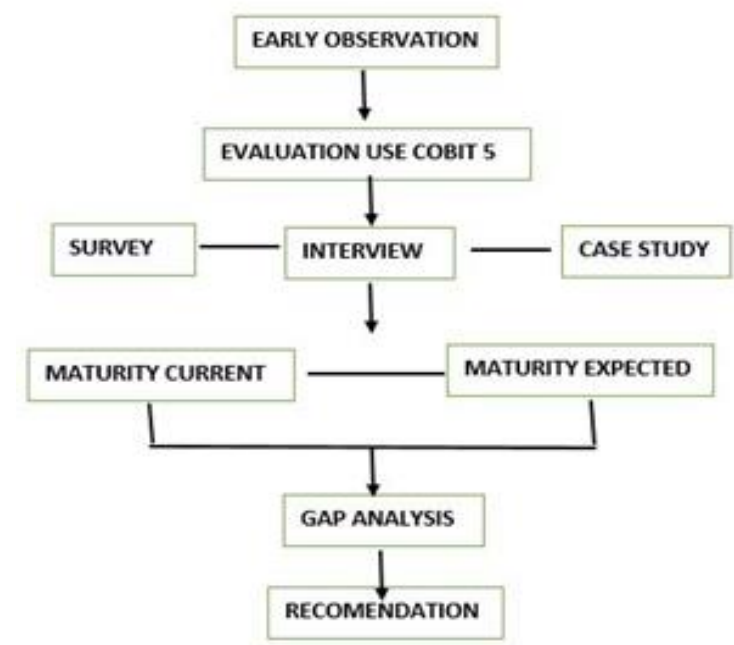

Figure 1. Research Method

The early observation or preliminary stage is the stage where the auditor team conducts preliminary observations and examines the problems that occur. Then evaluates the domain selection in the COBIT 5 framework related to problems that occur at Travelodge Hotel Batam.

The next stage is the stage of data collection. This stage after downgrading the COBIT 5 domain to a questionnaire item. Furthermore, conducting a survey using a questionnaire that has been made is shown to stakeholders (stakeholders) as respondents so that questions or statements of the questionnaire can be answered appropriately. Study documentation and interviews conducted to see and evaluate the current condition of the organization as data supporting the results of the questionnaire.

The data analysis technique which is carried out in 3 ways before formulating recommendations for improvement, the current maturity analysis is obtained from the results of data collection. Expected maturity analysis is obtained by interviewing the leaders of the organization or other managers. Next, a gap analysis is obtained by comparing the level between the expected level of maturity and the current level of maturity. the results of this comparison must be minimized by the organization within a certain time by implementing the recommendations for improvement provided.

\section{RESULT \& IMPLEMENTATION}

\section{A. Maturity Analysis}

In carrying out the capability level measurement process, it is necessary to determine what processes need to be measured with COBIT 5. First, maturity level analysis is evaluating the evaluation of each activity based on the results of the questionnaire. The assessment of maturity level is determined based on the scale of the level of maturity measurement (see Table I).

Table- I: Scale maturity

\begin{tabular}{|l|c|c|l|}
\hline No & Scala & Maturity Level & \multicolumn{1}{c|}{ Value } \\
\hline 1 & $0.00-0.50$ & Level 0 & In completed Process \\
\hline 2 & $0.51-1.50$ & Level 1 & Performed Process \\
\hline 3 & $1.51-2.50$ & Level 2 & Managed process \\
\hline 4 & $2.51-3.50$ & Level 3 & Established Process \\
\hline 5 & $3.51-4.50$ & Level 4 & Predicable, Process \\
\hline 6 & $4.51-5.00$ & Level 5 & Optimizing process \\
\hline
\end{tabular}

Then looks for the average value of each domain to get the current level of maturity (as-is). Based on the results of questionnaire calculations and the obit Process conducted at KMS Travelodge Hotel Batam, the results obtained is 0.51-1.50 or performed process (see Table II).

Table- II: The Current of Maturity Level

\begin{tabular}{|l|c|c|c|c|}
\hline No & Process & Current & $\begin{array}{l}\text { Maturity } \\
\text { Level }\end{array}$ & Value \\
\hline 1 & AP07 & 0.83 & Level 1 & Performed Process \\
\hline 2 & BAI4 & 1.5 & Level 1 & Performed Process \\
\hline 3 & DSS3 & 1.33 & Level 1 & Performed Process \\
\hline 4 & DSS6 & 1.17 & Level 1 & Performed Process \\
\hline 5 & MEA1 & 0.83 & Level 1 & Performed Process \\
\hline
\end{tabular}

After getting the current maturity level (as-is), the results obtained are not as expected. Then conducting interviews. The expected maturity level (to-be) with the Head of IT Accounting and MIS Department.

It is expected that the KMS at Travelodge Hotel Batam will be at capability level 3 (value 2.51 - 3.50 or established process). Table III shows the expected of maturity level.

Table- III: The Expected of Maturity Level

\begin{tabular}{|l|c|c|c|l|}
\hline No & Process & Expected & $\begin{array}{l}\text { Maturity } \\
\text { Level }\end{array}$ & \multicolumn{1}{|c|}{ Value } \\
\hline 1 & AP07 & 3 & Level 3 & $\begin{array}{l}\text { Established } \\
\text { Process }\end{array}$ \\
\hline 2 & BAI4 & 3 & Level 3 & $\begin{array}{l}\text { Established } \\
\text { Process }\end{array}$ \\
\hline 3 & DSS3 & 3 & Level 3 & $\begin{array}{l}\text { Established } \\
\text { Process }\end{array}$ \\
\hline 4 & DSS6 & 3 & Level 3 & $\begin{array}{l}\text { Established } \\
\text { Process }\end{array}$ \\
\hline 5 & MEA1 & 3 & Level 3 & $\begin{array}{l}\text { Established } \\
\text { Process }\end{array}$ \\
\hline
\end{tabular}

Published By:

Blue Eyes Intelligence Engineering

\& Sciences Publication

(C) Copyright: All rights reserved. 
Data on the gap between the current maturity level and the target are used to determine the process that should be prioritized for improvement the KMS. The gap analysis of the Capability Level of selected COBIT 5 processes and the determination of priorities for improvement.

It is to find out the level of gap between the current conditions and the expected conditions as well as the efforts that must be made to minimize the gap. Table IV shows the result of gap analysis.

Table- IV: the results of Gap Analysis

\begin{tabular}{|c|c|c|c|c|l|}
\hline No & Process & $\begin{array}{l}\text { The Rsult of } \\
\text { Expected } \\
\text { Maturity }\end{array}$ & $\begin{array}{c}\text { The result } \\
\text { of Curent } \\
\text { Maturity }\end{array}$ & $\begin{array}{c}\text { The } \\
\text { result of } \\
\text { gap } \\
\text { Analysis }\end{array}$ & Value \\
\hline 1 & AP07 & 0.83 & 3 & $\begin{array}{l}(3-0.83) \\
=2.17\end{array}$ & $\begin{array}{l}\text { Managed } \\
\text { process }\end{array}$ \\
\hline 2 & BAI4 & 1.5 & 3 & $\begin{array}{l}(3-1.5) \\
=1.5\end{array}$ & $\begin{array}{l}\text { Performed } \\
\text { Process }\end{array}$ \\
\hline 3 & DSS3 & 1.33 & 3 & $\begin{array}{l}(3-1.33) \\
=1.67\end{array}$ & $\begin{array}{l}\text { Managed } \\
\text { process }\end{array}$ \\
\hline 4 & DSS6 & 1.17 & 3 & $\begin{array}{l}(3-1.17) \\
=1.83\end{array}$ & $\begin{array}{l}\text { Managed } \\
\text { process }\end{array}$ \\
\hline 5 & MEA1 & 0.83 & 3 & $\begin{array}{l}(3-0.83) \\
=2.17\end{array}$ & $\begin{array}{l}\text { Managed } \\
\text { process }\end{array}$ \\
\hline
\end{tabular}

\section{B. Recommendation}

Recommendation is a suggestion that will be given to IT management for KMS improvement needs. The proposed improvements made are directed so that the company can reach the level of maturity as expected. Based on the gap analysis obtained with the target level to be achieved in APO07, the condition of the current capability level is at level 1 while that is expected to be at level 3 . There are several recommendations for improvements suggested to improve the quality of KMS at Travelodge Hotel Batam , namely: (1). Identify each employee's needs that are tailored to the needs of KMS; (2) Optimizing knowledge-sharing culture in overcoming critical matters so as to reduce individual dependency; and (3) Making SOP for the process of using the KMS.

Based on the gap analysis obtained by BAI4, the maturity currently is level 1 , while expected to be at level 3 . There are several recommended improvements to improve the quality of KMS at Travelodge Hotel Batam, namely: (1) plan the availability of knowledge; (2) making knowledge documentation; (3) establish requirements for knowledge documentation; and (4) evaluate system performance.

Based on the gap analysis obtained by DSS3, the maturity currently is level 1 , while expected to be at level 3 . There are several recommended to improve the quality of KMS at Travelodge Hotel Batam, namely: (1) determine the priority level of problems in solving problems in a timely manner for KMS; and (2) creating a KMS that can find out the tricking system for employees.

Based on the gap analysis obtained by DSS6, the maturity currently is level 1 , while expected to be at level 3 . There are several recommended to improve the quality of KMS at Travelodge Hotel Batam, namely: (1) prepare procedures for managing the knowledge process without interfering with the running business operations; (2) prepare KMS change strategy; and (3) evaluating the effectiveness of the ongoing KMS.

Based on the gap analysis obtained by MEA1, the maturity currently is level 1 , while expected to be at level 3 . There are several recommended to improve the quality of Travelodeg Hotel Batam.

\section{REFERENCES} Management Focus, 2. Tourism Review, 73(3), 359-373. Management, 4(4), 225-252. IEEE.

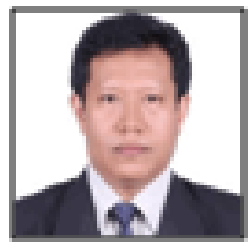
approach regarding monitoring activities to define the goals, scope and knowledge of KMS services; (2) monitoring the KMS performance process; and (3) creating a system for measuring employee performance in the use of KMS.

\section{CONCLUSION}

Maturity level obtained in evaluation through Cobit 5 at Travelodge Hotel Batam precisely on KMS (Knowledge Management System) is at level 1. Meanwhile, based on interviews with TI Division Heads and other Managers and General Managers, information is obtained that the desired

er, based on the gap analysis obtained with the targe several recommendations related to the maturity leve

1. Evans, James R. dan William M. Lindsay. 2007. An Introduction to Six Sigma and Process Improvement. Jakarta : Salemba Empat.

2. Shekar Sivasubramanian: 2016, Process Model Knowledege

3. Dalkir, Kimiz. (2011). Knowledge management in Theory and Practice. Massachusetts Insitute of Technology.

4. Aliquo Jr, J. F., CISA, C., \& Fu, Z. (2014). DuPont drives continuous improvement with COBIT 5 process assessment model. COBIT

Naser, S. S. A., Al Shobaki, M. J., \& Amuna, Y. M. A. (2016) Measuring knowledge management maturity at HEI to enhance performance-an empirical study at Al-Azhar University in Palestine.

7. Šajeva, S., \& Jucevičius, R. (2010). Model of knowledge management system maturity and its approbation in business companies. Socialiniai mokslai, (3), 57-68.

8. Kaner, M., \& Karni, R. (2004). A capability maturity model for knowledge-based decisionmaking. Information Knowledge Systems

9. Picard, M., Renault, A., \& Barafort, B. (2015, September). A maturity model for ISO/IEC 20000-1 based on the TIPA for ITIL process capability assessment model. In European Conference on Software Process Improvement (pp. 168-179). Springer, Cham.

10. Hartono, S., Tjahyadi, R., \& Cassandra, C. (2019, August). Analysis of Trouble Ticket System Using COBIT 5 Framework (A Case Study Approach). In 2019 International Conference on Information Management and Technology (ICIMTech) (Vol. 1, pp. 420-425).

\section{AUTHORS PROFILE}

Dr. Sfenrianto, S,Kom, M.Kom is a Faculty Member of the Information Systems Management Department, BINUS Graduate Program - Master of Information Systems Management, Bina Nusantara University, Jakarta 11480, Indonesia. (e-mail: sfenrianto@binus.edu). With lecturing subject: Digital Business and E-Commerce Management. Research interest in Digital Business, e-Commerce, business intelligence, E-Learning and Information System. 
Maturity Level Knowledge Management System at Travelodge Batam Hotel using the Cobit 5 Framework

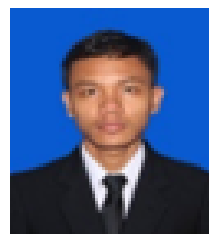

Muhamad Dody Firmansyah is a graduate of Master of Information Systems Management, Bina Nusantara University, Jakarta 11480, Indonesia. He was working as Front End Developer at PT Intelligence Studio Nusantara. Research interest in Information system, e-Commerce, Programming, and Computer Application.

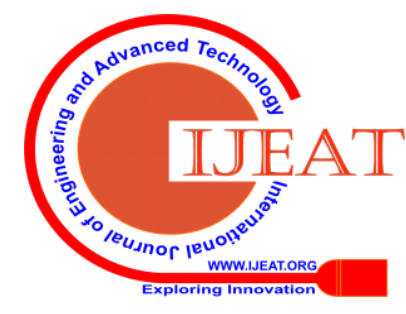

